\title{
REFLEXIVE COMPETENCE OF KINDERGARTEN TEACHERS
}

\section{[REFLEXIVNA KOMPETENCIA UCITELOV MATERSKYCH SKOL]}

\section{Eva Pupikova}

\section{doi: 10.18355/PG.2016.5.2.363-377}

\begin{abstract}
The aim of the theoretical study is to analyze approaches to compile the professional competences of teachers of pre-primary education. Professional competences of a kindergarten teacher are partially different from other sub-categories of teachers. The author's intention is to point out to the specifications of professional competences of a kindergarten teacher. The main focus is on reflexive competence of teachers, which is the common intersection of all the division of competences. The reflexive competence of a teacher can just be seen as the main carrier of the changes taking place in the educational process and bringing a positive qualitative changes at schools. In the final part of the article, the author focuses on the determinants which are related with a given competence and which are prerequisite to the achievement of it.
\end{abstract}

\section{Keywords}

professional competences of teachers, reflexive competence, reflection, diagnosis, evaluation

\begin{abstract}
Abstrakt
Ciel'om teoretickej štúdie je analyzovat' prístupy k zostaveniu súboru profesijných kompetencií učitel'ov predprimárneho vzdelávania. Profesijné kompetencie učitel'a materskej školy sa čiastočné odlišujú od iných podkategórii učitel'ov. Zámerom autorky je poukázat' na špecifiká profesijných kompetencií učitel'a materskej školy. Hlavný doraz je kladený na spoločný priesečník všetkých delení kompetencií, ktorým je reflexívna kompetencia učitel'ov. Práve reflexívnu kompetenciu učitel'a možno vnímat' ako hlavnú nositel'ku zmien, ktoré sa uskutočňujú vo výchovnovzdelávacom procese a prinášajú pozitívne kvalitatívne zmeny v školách. V záverečnej časti príspevku sa autorka sústredí na vysvetlenie základných pojmov, ktoré $\mathrm{s}$ danou kompetenciu súvisia a sú predpokladom $\mathrm{kjej}$ dosiahnutiu.
\end{abstract}

Kl'účové slová

profesijné kompetencie učitel'ov, reflexívna kompetencia, reflexia, diagnostika, evaluácia

Úvod

Klúčovým prvkom, vedúcim ku zmene $\mathrm{v}$ našich školách, je zmena myslenia učitel'a. Už v 19. storočí na to upozorňoval ruský pedagóg K. 
Usinskij ked' hovoril, že „učitel' je kl'účová osoba reformovania vzdelávania. Vo výchove a vzdelávaní sa nedá nič väčšie zmenit', ako je hlava učitel'a“ (Barabanova, 2012). V nasledujúcom príspevku sa chceme venovat' profesijným kompetenciám učitel'ov materských škôl. Hlavný dôraz budeme v príspevku klást' na reflexívnu kompetenciu, ktorá je kl'účovou pri zmenách myslenia učitel'a. Učitel' premýšl'ajúci nad svojou pracou, mení svoje konanie, správanie, rozhodovanie. Pokúsime sa nájst' odpoved' na otázku, čo je podstatou reflexívnej kompetencie učitel'a. Aké schopnosti potrebuje k tomu, aby dokázal hodnotit' svoje konanie.

\section{Profesijné kompetencie učitel'a}

Učitel'om je podl'a J. Prucha et al. (1995: 151) „osoba podiel'ajúca sa na výchove a vzdelávaní detí“. V materských školách, ktoré sú prvým stupňom školskej sústavy, je to učitel' materskej školy. $\mathrm{Ku}$ kvalitnému vykonávaniu povolania učitel’a materskej školy je potrebné splnit' niekol'ko základných požiadaviek. Prvými sú požiadavky, ktoré vyplývajú zo Zákona o pedagogických zamestnancoch a odborných zamestnancoch ${ }^{1}$. Absolvent pregraduálnej prípravy, nastupuje na výkon povolania do materskej školy, kde sa k legislatívnym požiadavkám pridávajú d'alšie požiadavky, ktoré sa od učitel'a očakávajú. J. Prucha (2009: 188) vo svojej publikácii uviedol, že snaha o pomenovanie základných charakterových osobitostí učitel'a nie je novodobým fenoménom. Už v minulosti sa za najdôležitejšie rysy učitel’ov preferovali:

- Motivácia k povolaniu;

- talent pre povolanie - učitel'ská schopnost';

- kognitívna vybavenost'.

Požiadavky, kladené na učitel'a, môžeme v súčasnosti označit' slovným spojením profesijné kompetencie učitel'a. Pedagogicky slovník (Prucha, Walterova, Mares, 2001: 103-104) uvádza, že kompetencia je ,súbor profesijných schopnosti a dispozícii, ktorými má byt' vybavený učitel', aby mohol efektívne vykonávat' svoje povolanie“. Kompetencie viažuce sa na profesiu učitel’a chápe V. Spilkova et al. (2004: 25) ako „pedagogické spôsobilosti ul'ahčujúce učitel'ovi zvládanie zložitých a premenlivých situácii“. H. Belz a M. Siegrist (2001: 27) uvádzajú, že kl'účové kompetencie sú výrazom schopnosti človeka správat’ sa v situácii primerane a adekvátne v súlade so sebou samým. Učitel' vtedy koná kompetentne. J. Prucha (2002: 106) upozorňuje na to, že kompetencie učitel'a nie sú iba získanými vedomost'ami a zručnost'ami počas prípravy na výkon povolania, ale je to aj vrodená dispozícia na výkon povolania učitel'a. Učitel'ské kompetencie teda vnímame ako súbor vedomostí a zručností získané vzdelávaním, ktoré spolu s vrodenými dispozíciami na výkon povolania umožňujú učitel'ovi vykonávat' činnosti spojené s povolaním.

Pokusy o stanovanie základných profesijných kompetencií vychádzajú $\mathrm{z}$ rôznych prístupov. Domnievame sa, že jednotlivé prístupy k rozdeleniu kompetencii sa od seba odlišujú podl'a toho, čo je pre zostavovatel'a súboru kompetencií prioritnejšie. H. Belz a M. Siegrist (2001: 27) charakterizujú tri základné prístupy k zostavovaniu súboru kompetencií. 
Prvým prístupom je prístup kognitívny. Tento prístup $\mathrm{k}$ deleniu kompetencií je založený na hodnotení a porovnávaní mentálnych schopností človeka. Kompetencie možno zadefinovat' ako chápanie pojmov, vytváranie úsudkov a záverov, schopnosti riešit' problémy, schopnosti kritizovat', schopnosti reflektovat'. Uvedené schopnosti sú všeobecné, bez prepojenia na konkrétne povolanie.

Ďalší prístup delenia klúčových kompetencií je prístup zameraný na spoločnost'. Podstata tohto prístupu spočíva $v$ snahe zachytit' kompetencie potrebné k pokračovaniu a napredovaniu celej spoločnosti. Oskar Negt (Belz - Siegrist, 2001: 31) hovorí o schopnosti človeka mysliet' v súvislostiach, technických kompetenciách, ekologických kompetenciách a kompetenciách v poznávaní zmysluplnosti. Oblast', v ktorej hovorí autor ako o schopnosti človeka poznat' zmysluplnost' svojej činnosti, možno nájst' kompetencie zamerane na reflexiu vlastnej činnosti a chápanie jej významu. B. Kasacova, B. Kosova (2006: 34) v rámci tohto prístupu hovoria o hl'adisku ,požiadaviek rozvíjajúcej sa spoločnosti zo strany rodiny, regiónu, štátu, Európy." Takto zatriedené kompetencie opisujú ideálneho človeka 21. storočia. V Odporúčaní Európskeho parlamentu a rady z 18. decembra 2006 o klúčových kompetenciách pre celoživotné vzdelavánie $^{2}$ bol uvedený referenčný rámec pre celoživotné vzdelávanie. Obsahuje osem klúčových kompetencii, ktoré potrebujú občania vyspelej Európy na to, aby boli schopný začlenit sa do spoločnosti. Sú to kompetencie, ktoré s konkrétnym povolaním priamo nesúvisia.

Delenie kompetencií podla predchádzajúcich dvoch prístupov, kognitívneho a prístupu zameraného na spoločnost', možno zjednodušene označit' za nadprofesijné, spoločné pre všetkých l'udí bez vplyvu na povolanie. Súhlasíme, že takto zadefinované kompetencie sú zostavené v záujme napredovania celej spoločnosti. Domnievame sa však, že povolanie učitel'a si svojou špecifikáciou vyžaduje stanovenie d'alších, diel'čích kompetencií, ktoré sa vzt’ahujú na výkon konkrétneho povolania učitela. Tento fakt rešpektuje tretí prístup definovania kompetencií, ktorý je založený na analýze činnosti. Berie do úvahy najmä činnosti, ktoré učitel' vykonáva pri výkone svojho povolania. Pokúša sa zosumarizovat' základné predpoklady a schopnosti zamestnanca, $v$ našom prípade učitel'a materskej školy. Tie potrebuje učitel' „, pružnému zvládaniu situácii v zamestnaní“ (Belz - Siegrist, 2001: 28). B. Kasacova, B. Kosova (2006: 34) hovoria „o hl'adisku konkrétneho kontextu edukačných situácií“, teda kompetencie učitel'a a ich delenie, ktoré sú $\mathrm{v}$ súlade $\mathrm{s}$ činnost'ou učitel'a a vyplývajú z nej. Napr. učitel' musí byt schopný naplánovat' svoju výchovnovzdelávaciu činnosti. Pri plánovaní by mal vediet', aké základné didaktické zásady by mal rešpektovat', ako postupovat' pri plánovaní vychádzajúc $\mathrm{z}$ aktuálneho kurikulárneho dokumentu pre materské školy, z aktuálnej legislatívy. Učitel' by mal byt schopný samostatne realizovat' svoju výchovno-vzdelávaciu činnost' a následne hodnotit' svoje výsledky. Podl’a H. Belz a M. Siegrist (2001) tento prístup hovorí okrem iného aj o kompetenciách učitel'a vykonávat' svoju činnost' samostatne. Učitel' je, vo väčšine svojej priamej práce s det’mi, samostatne konajúcim človekom, napriek tomu, že je súčast'ou pedagogického kolektívu. Na to nadväzuje 
d'alšia kompetencia učitel'a, ktorou je schopnost' pracovat' v tíme, rešpektovat' a napĺn̆at' spoločné vízie a ciele školy. Súhlasíme s autormi $H$. Belz a M. Siegrist (2001), ktorí uvádzajú tímovú kompetenciu za jednu z kl'účových kompetencií. Učitel' by mal poznat' vlastné zameranie svojej školy, mal by s ním byt' stotožnený a v prípade opaku, mal by byt' schopný svoje názory a postoje obhájit' v kolektíve s rešpektovaním základných pravidiel tímovej prace. Uvedení autori uvádzajú d'alšiu kompetenciu, ktorou je systémová kompetencia, čiastočne korešpondujúca s tímovou kompetenciou. Zahrňuje schopnost' systémovo pristupovat' k práci, schopnost' prijat' jednotný ciel' materskej školy a následne fungovat' v záujme jeho plnenia. Posledná vel'ká skupina kompetencií zahŕn̆a reflexívne kompetencie.

Za klasické delenie podl'a tohto prístupu považujeme delenie Ch. Kyriacou (2012: 21-22), ktorý vymenoval základné činnosti, ktoré učitel' vykonáva. Nie všetky činnosti, ktoré vymenoval, sú v úplnej kontinuite s povolaním učitel' materskej školy. B. Kasacova (2006) kombinovaním viacerých prístupov, považuje za kl'účové tri základné oblasti kompetencií učitela. Prvou je oblast' personálna. Možno sem zahrnút' osobnostné predpoklady k vykonávaniu učitel'ského povolania; druhou je oblast' etická, ktorú by sme mohli označit' za nadprofesijnú, pretože je potrebná u všetkých, bez ohl'adu na druh vykonávaného povolania. Tretou oblast'ou je odborná dimenzia. Kompetencie, ktoré z nej vyplývajú súvisia s vykonávaním konkrétneho zaradenia učitel'a, jeho odborovej profilácie. Učitel' ju dosahuje najmä svojim pregraduálnym vzdelávaním. Možno sem zaradit' vedomosti, zručnosti, schopnosti, ktoré sú nevyhnutým prvotným predpokladom na výkon povolania. Medzi základné kompetencie učitel'a možno podl'a G. Porubska (2007: 36-37) zaradit':

1. Kompetencia pedologická - schopnost' diagnostikovat' a následne pracovat's konkrétnou skupinou edukantov;

2. kompetencia odborná - zvládnutie príslušného odboru;

3. kompetencia komunikačná - efektívna komunikácia aj v cudzích jazykoch;

4. kompetencia pedagogicko-organizačná - vytváranie optimálneho prostredia, plánovanie a projektovanie;

5. kompetencia poradenská a konzultačná - schopnost' pomôct' účastníkom pri riešení problémov;

6. kompetencia kvalifikovanej pedagogickej sebareflexie;

7. kompetencia personálna a interpersonálna - vediet' sa presadit' (asertivita), ale aj vcítit'sa do pozície iných (empatia);

8. kompetencia didakticko-technologická.

Zostavenie súboru základných kompetencií pre učitel'ov v jednotlivých kategóriách a podkategóriach, ktoré by boli akceptované celou spoločnost’ou, dostala za úlohu pracovná skupina odborníkov ${ }^{3}$. Pri ich príprave sa autori inšpirovali modelom Osera, ako uvádzajú B. Kasacova a B. Kosova (2006: 41). Návrh profesijného štandardu je kombinovaním všetkých troch vyššie spomenutých prístupov, a to prístupu kognitívneho, osobnostného a hodnotového. Tvorí ho súbor kompetencií, pre jednotlivé 
kategórie a podkategórie pedagogických zamestnancov. Kompetencie sú zostavene podl'a karieroveho stupňa, na ktorom sa učitel' nachádza a tiež od pregraduálnej prípravy. Príprava učitel'a materskej školy neprebieha len na pedagogických fakultách, ale aj na stredných odborných školách. To je dôvodom, prečo je pre dosiahnutý stupeň pregraduálnej prípravy, stanovený kvalitatívne iný súbor kompetencii. Profesijný štandard rešpektuje legislatívne vymedzenie kvalifikačných predpokladov učitel’a materskej školy.

Napriek rozmanitosti definícií a skladbe kompetencií českí odborníci uvádzajú, že „,väčšina modelov zahíňa do popisov charakteristík klúčových prvkov kvality učitel'ov spoločné dimenzie: vedomosti (predmetové $\mathrm{v}$ kurikulárnych oblastiach, pedagogicko-psychologické a odborovo didaktické, všeobecný rozhl'ad), pedagogické a didaktické zručnosti (týkajúce sa najmä komunikácie a interakcii, sociálnej klímy, vyučovacích stratégií a riadenie procesov učenia, diagnostiky a hodnotenia deti, spolupráce s kolegami a rodičmi, reflexia výučby a sebareflexia, postoje, hodnoty a osobnostné vlastnosti“" (Tomkova, et al., 2012: 6).

Je potrebne tiež podotknút', že dosiahnutie jednotlivých kompetencií nie je jednoduchá a jednorazová záležitost'. H. Belz a M. Siegrist (2001: 27) uvádzajú podl'a Richtera, že „dosahovanie klúčových kompetencií je celoživotný proces, ktorý je udržovaný dynamikou nového učenia a preučovania." Učitel' si svoje kompetencie dopíňa, rozvíja, ale aj mení počas svojho kariérneho pôsobenia. Hlavným dôvodom, sú neustále zmeny v politickom, sociálnom, axiálnom systéme dnešnej civilizácie, na ktoré musí učitel' reagovat'.

Názorov na profiláciu potrebných kompetencii na výkon povolania učitel’a je vel'a. Vyplýva to v prvom rade z prístupov, o ktorých sme sa zmienili vyššie. Domnievame sa, že iba kombináciou rôznych prístupov možno vytvorit' súbor kompetencií, ktoré by obsahovali všetky potrebné schopnosti, zručnosti, vedomosti, potrebné na zvládanie učitel'ského povolania.

\section{Profesijné kompetencie učitel’a materskej školy}

Kompetenciám učitel'ov materských škôl sa samostatne venovali napr. V. Mertin a I. Gilnerova (2010: 28), ktorí uvádzajú štyri základné oblasti schopností, ktoré by mal učitel predprimárneho vzdelávania dosiahnut': sociálnopsychologické schopnosti; odborové schopnosti; metodické profesijné schopnosti; špecialnovýchovné a diagnostické profesijné schopnosti. H. Horka, J. Havel (2010: 133-135) delia kompetencie učitel'ov materských škôl až do siedmych kategórii. Za základné kompetencie považujú kompetencie odborové a psychodidaktické. Na ne nadväzujú kompetencie pedagogické, diagnostické a intervenčné, psychosociálne a komunikatívne, manažérske a napokon kompetencie profesijné a osobnostne kultivujúce.

Zatial' iba $\mathrm{v}$ pracovnej verzii profesijných štandardov učitel'ov sú zadefinovane tri vel'ké dimenzie kompetencií učitel'ov predprimárneho vzdelávania. Kompetencie sú tu vnímané ako očakávané vedomosti a spôsobilosti učitel'a: 
- Prvá dimenzia kompetencií je zameraná na poznanie, diagnostikovanie diet'at'a a všetkých faktorov, ktoré majú na diet’a vplyv a ktoré sú hlavnými determinantmi pri dosahovaní výchovných a vzdelávacích ciel'ov.

- Druhou dimenziou profesijných kompetencií sú zručnosti, vedomosti, ktoré sú dôležité pri samotnej realizácii výchovnovzdelávacej činnosti. Táto dimenzia obsahuje kompetencie, ktoré učitel' potrebuje na to, aby vedel projektovat', realizovat' a hodnotit' výchovno-vzdelávaciu činnost'.

- Tret'ou dimenziou je oblast' kompetencií, ktoré učitel' má dosahovat', aby v prvom rade chcel, vedel a naozaj realizoval svoj vlastný sebarozvoj.

Na základe porovnania s vyššie uvedenými kompetenciami sa niektorým kompetenciám chceme bližšie venovat', vzhl’adom ku špecifikácii povolania učitel'a materskej školy. Budeme vychádzat' $z$ návrhu profesijného štandardu. V dimenzii Výchovno-vzdelávacieho procesu je uvedená kl'účová kompetencia učitel'a Ovládat' obsah predprimárneho vzdelávania. Od učitel'a materskej školy sa neočakáva, že bude špičkovým odborníkom iba v jednej oblasti, ako napr. učitel' druhého stupňa základnej školy, ktorý vyučuje konkrétny predmet. Od učitel'a materskej školy prax vyžaduje zvládnutie základov všetkých odborov, či už prírodovedných, spoločenských, umeleckých alebo technických. M. Lipnicka (2009: 196) podl'a Kosovej uvádza, že učitel' materskej školy musí mat' prehl'ad vo všetkých oblastiach, tak, aby bol schopný odovzdávat' svoje vedomosti v súlade so základnými didaktickými princípmi. E. Opravilova (2010:. 44) v podobnom duchu, kladie doraz skôr na odborovodidaktické kompetencie, ako na iba odborove. Súhlasíme, že pre učitel'a materskej školy je podstatnejšie dosiahnut' kompetencie, ktoré mu umožňujú efektívne zrealizovat' svoj edukačný zámer v jednotlivých odboroch, ako vel'ký rozsah vedomostí z jednej konkrétnej oblasti.

Ďalším špecifikom povolania učitel' materskej školy, je výkon priamej vyučovacej povinnosti. Učitel' materskej školy vykonáva priamu činnost' s det'mi bez prestávky, nepretržite, čo si nutne od neho vyžaduje schopnost' uvedomit' si všetky povinnosti, systematizovat' ich, pripravit' sa na ich zvládanie a tiež schopnost' operatívne reagovat' na vzniknuté situácie. Učitel' materskej školy by mal zvládnut' a zabezpečit' bezpečnost' deti v záujme individuálnych potrieb jednotlivcov. Organizačná štruktúra denného poriadku v materskej škole je oproti iným stupňom škôl podstatne odlišná. Funkcie jednotlivých organizačných foriem sú rôzne, preto si od učitel'a vyžadujú iné schopnosti a zručnosti. Napr. pri hrách podl'a výberu detí je úlohou učitel'a vytvárat' vhodné prostredie na hru, byt' spoluhráčom, pri stagnácii hry detí sa od učitel'a vyžaduje „pomoc“ - intervencia, ktorá posunie hru, zmení nenásilne smer hry a pod. „Profesionálne pochopit’ hru diet'at'a v predškolskom veku, vediet' sa hrat', učit' sa ako učit' seba a deti hrat' sa, erudovane projektovat' hry a hrové činnosti, realizovat' a evalvovat' hru“ označila M. Podhajecka (2011: 22) ako hrovú kompetenciu učitel'a. Uvedenú kompetenciu nachádza Podhajecka vnorenú vintenciách 
kompetencii pedagogických, psychodidaktických, organizačných, a pod., podl'a delenia d'alších autorov. Počas vzdelávacej aktivity, ktorá je nosnou vzdelávacou formou v materskej škole, je úloha a funkcia učitel'a čiastočne odlišná. Domnievame sa, že učitel' materskej školy, ktorý pozná teoretické základy hry, pozná jej význam, využitie a ma zároveň schopnost' „hrat' sa“, dokáže l'ahšie plnit' edukačné ciele u takej špecifickej vekovej skupiny, akou sú deti predškolského veku. Dôležitou schopnost'ou učitel'a je tiež efektívne využívanie vzniknutých neplánovaných situácii a tiež využívanie situácii, v ktorých je diet’a konfrontované so sociálnou realitou, uvádza D. Kollarova (2012: 182).

Za špecifikum prace učitel'a materskej školy považujeme aj vel'mi intenzívny vzt'ah učitel' - rodič. Vyplýva to samozrejme z legislatívy, veku detí a vnútorných predpisov materskej školy, v ktorých sú ustanovene podmienky preberania a odovzdávania detí. Výsledkom je každodenný kontakt učitel'a s rodičom diet'at'a. Kontakt s rodičmi nie je na žiadnom d’alšom vzdelávacom stupni taký intenzívny, ako práve počas dochádzky diet'at’a do materskej školy. Domnievame sa, že táto skutočnost' je kl'účová pri vytváraní budúceho vzt’ahu rodina - škola. Preto schopnost' zvládnut' profesionálne tento fakt, by mala byt' premietnutá do kompetencií učitel'a predprimárneho vzdelávania. M. Lipnicka (2009: 194) hovorí o poradenskej a konzultačnej kompetencii. Profesijné štandardy niektorých iných krajín majú vo svojom profesijnom štandarde zakotvené kompetencie v oblasti spolupráce s rodinou v ovel’a širšom kontexte. Napr. v Ruskej federácii je súčast'ou profesijného štandardu kompetencia spolupráce s rodinou. Učitel' by mal „vediet' podporit' výchovnú snahu rodičov a vediet' priviest' rodičov $\mathrm{k}$ riešeniu výchovných problémov ich detí', mal by tiež poznat' „základné zákonitosti rodinných vzt'ahov, čo umožňuje efektívne pracovat' s rodinnou komunitou“, mal by poznat' a používat' „metódy a prostriedky psychologicko-pedagogického vzdelania rodičov (zákonných zástupcov), dojčiat a detí predškolského veku, aby bolo možné budovat' partnerstvá $\mathrm{s}$ rodičmi pri riešení výchovných problémov"“4. V návrhu profesijného štandardu pre učitel’ov predprimárneho vzdelávania nachádzame kompetenciu, ktorá nepriamo súvisí s rodinou. Je ňou kompetencia Identifikovat' sociokultúrny kontext vývinu diet’ata.

\section{Reflexívna kompetencia učitel'a materskej školy}

Z predchádzajúceho textu vyplýva, nás zaujal fakt, že všetky delenia profesijných kompetencií majú jednu spoločnú oblast'. Je to oblast', ktorá je zameraná na schopnost' človeka vnímat' seba samého, poznat' seba samého a následne schopnost' menit' seba samého z dôvodu zlepšit' svoju činnost', uskutočňovat' svoj vlastný sebarozvoj. Táto schopnost' je zadefinovaná $\mathrm{v}$ Odporúčaní Európskeho parlamentu a rady z 18. decembra 2006 o klúčových kompetenciách pre celoživotné vzdelávanie. Uvádza sa v ňom, že piatou kl'účovou kompetenciou je kompetencia Naučit' sa učit'. Jej hlavným zmyslom je priviest' jednotlivca $\mathrm{k}$ tomu, aby staval na predchádzajúcom vzdelávaní a životných skúsenostiach a využival ich v d'alšom svojom pôsobení. Táto kompetencia vyžaduje od jednotlivca, aby poznal silné a slabé stránky svojich zručností a kvalifikácií, a aby bol 
schopný vyhl'adávat' d’alšie príležitosti na vzdelávanie sa. Kompetencia Naučit' sa učit' obsahuje v sebe schopnost' poznat' samého seba, v kontexte prebiehajúcich situácii, uvedomenie si svojich kladov a záporov.

„Umenie formulovat’ priliehavý profesijný úsudok je výrazom kl’účových dispozícii učitel'ov - dispozícii, ktoré sú v súčasnej dobe pomenované najmä termínmi profesijné videnie alebo reflexívna kompetencia učitel'ov (Slavik, et al., 2015: 6). D. Goleman (1997) zhrnul výsledky viacerých výskumov zameraných na faktory, ktoré očakávajú zamestnávatelia od svojich pracovníkov. Zoradil jednotlivé výsledky podl’a dôležitosti. Na prvé miesta umiestnil práve schopnost' učit' sa, rozvíjat' pracovné zručnosti a zlepšovat' pracovný výkon. V podobnom duchu G. Petrova, J. Duchovicova (2015: 198) vyzdvihujú vhl'ad učitel'a do vzt'ahu podmienok a dôsledkov svojho konania. Možno hovorit' o nadprofesijnej kompetencii človeka poznat' svoje silné a slabé stránky a schopnosti vediet' zlepšovat' svoje konanie. V prípade, že ide o povolanie učitel'a, mohli by sme túto kompetenciu doplnit' Naučit' sa učit' sa učit', čo zasahuje do profesijnej oblasti. Vo všetkých deleniach kompetencií je práve táto kompetencia spoločným priesečníkom. H. Horka, J. Havel (2010: 133-135) zarad'ujú tuto schopnost' učitel'a do kompetencií profesijných a osobnostne kultivujúcich, kde uvádzajú nutnost' mat' schopnost' vykonávat' autoevaluáciu - ,ako predpoklad svojho rozvoja a zmeny kvality školy“. Kvalita školy je podmienená pravé myslením a zmenami v myslení učitel'a. G. Porubska (2007: 36-37) uvádza kompetenciu kvalifikovanej 370 pedagogickej sebareflexie - pričom dôraz kladie hlavne na analýzu vplyvu na konanie vzdelávaných, ale aj schopnost' hodnotit' vlastnú pedagogickú činnost' s ciel'om jej zlepšenia. Ch. Kyriacou (2012) hovorí o reflexii vlastnej práce a evaluácii. „Reflexívna kompetencia robí človeka byt' schopným hodnotit' po kritickom porovnaní vlastný výkon podl'a dosiahnutých výsledkov. Pochopit' ustálené spôsoby reakcií a rutín, ujasnit' si vlastné pohnútky a meradlá hodnôt", uvádzajú $\mathrm{H}$. Belz a M. Siegrist (2001: 29). Návrh profesijného štandardu rozvoja učitel'a predprimárneho vzdelávania obsahuje vdimenzii Sebarozvoj profesijnú kompetenciu: Reflektovat' vlastnú pedagogickú činnost' a využívat' ju pre d'alší odborný a profesijný rozvoj. J. Pelikan (2011: 30) uvádza, že ,adekvátna sebareflexia je dôležitá k tomu, aby človek pochopil svoje možnosti a dokázal sa stat' subjektom vlastného konania, samostatnosti osobnosti“. Definovanie reflexívnej kompetencie učitel'a má vo všetkých deleniach spoločnú črtu. Sú ňou schopnosti učitel'a hodnotit' seba samého a vnútorná motivácia učitel'a vykonávat' zmeny. Najskôr sú to zmeny v správaní a konaní učitel'a, ktoré majú neskôr dopad na zmeny tykajúce sa celej školy.

\section{Diagnostika verzus reflexia verzus evaluácia}

B. Kasacova, B. Kosova (2007: 6) bližšie špecifikujú reflexívnu kompetenciu, ako „schopnost' profesijného rastu a sebarozvoja schopnost' reflektovat', diagnostikovat', hodnotit' vlastnú pedagogickú ' činnost', plánovat' si vlastný rast a vzdelávanie, mat' všeobecný kultúrny a občiansky rozhl'ad, poznat' trendy vývoja spoločnosti a vzdelávania, byt'

Slavonic Pedagogical Studies Journal, ISSN 1339-866o, Volume 5 Issue 2, September 2016 
metodologicky vybavený pre učitel’ský výskum“. Definície reflexívnej kompetencie učitel'ov vel'mi často obsahujú rôzne pojmy. V literatúre sa stretávame s používaním pojmov, napr. diagnostika, autodiagnostika, reflexia, sebareflexia, evaluácia, autoevaluácia, hodnotenie, sebahodnotenie. Jednotlivé pojmy vnímame ako procesy, ktoré priamo súvisia s reflexívnou kompetenciou. Z lexikálneho hladiska, v prípade použitia predpony auto- (z gréckeho slovníka) - znamená sám, sama, samé, seba, môžeme hovorit' o činnosti, jave, vlastnosti, ktorá je zameraná na seba samého. V nasledujúcich riadkoch sa pokúsime o analýzu jednotlivých pojmov.

Diagnostika je podla Pedagogického slovníka (Prucha, Walterova, Mares, 2001) „zaradenie objektu, javu, znaku do konvenciami stanovenej diagnostickej kategórie“. Diagnostika, ako spojenie dvoch gréckych slov dia-, ktoré znamená osobitne, oddelene, híbkovo a -gnosis, číže poznanie, možno vol'ne prelozit', ako oddelené poznávanie, rozpoznávanie alebo híbkové poznávanie rôznych oblastí. Autodiagnostika teda znamená zmyslové a rozumové poznanie, jednotlivých oblastí vlastných schopnosti, zručnosti, návykov, vlastností a pod. Poznanie svojich osobnostných dispozícií je potrebné $\mathrm{z}$ dôvodu chápania vlastného správania a konania. V. Svec (1994) vymedzuje autodiagnostiku ako proces, v priebehu ktorého získava a spracováva spatnoväzbové informácie. Zvlášt' upozorňuje na to, že musí ist' o cielené a systematické získavanie spatnoväzbových informácií. Na vykonávanie autodiagnostiky možno využit' rôzne nástroje a metódy, ktorými môžeme získavat' odpovede na otázku Aký som?. Pri realizovaní autodiagnostiky si môžeme pomôct' napr. testami, pozorovaním vlastných videonahrávok, dotazníkmi. Pomocou nich môže zistit' informácie napr. o vlastnom temperamente, o tom, aký učebný štýl používame, a pod. Vychádzat pritom môžeme z poznatkov psychológie osobnosti. S. Babiakova (2014: 49) stanovuje diagnostiku ako „naučenú schopnost', profesijnú spôsobilost', resp. zručnost' jedinca diagnostikovat' javy“. Výsledky autodiagnostiky môžu pomôct' učitel'ovi pochopit’ situácie, ktoré si pomocou sebareflexie/reflexie uvedomuje. Môžu mu dat' odpovede na otázky napr. „Ovplyvnili moje osobnostné predpoklady moje konanie v danej situácii?. Výsledky autodiagnostiky môžeme porovnávat's normou. Za normu môžeme považovat' napr. profesijné štandardy, podl'a ktorých si učitelia môžu porovnávat' dosiahnutie svojich profesijných kompetencii, ale aj rôzne testy osobnosti, ktorými môžu učitelia hodnotit' svoje osobnostné kompetencie. V. Spilkova (2004) definuje autodiagnostiku ako schopnost' porozumiet' sebe samému, odpovedat' si na otázky Kto som? Aký som?. Diagnostiku teda vnímame ako činnost', ktorú môže učitel' vykonávat' za predpokladu, že ma dosiahnuté vedomosti, zručnosti, získané najmä pregradulanou prípravou alebo d’alším vzdelávaním.

Reflexívna kompetencia $\mathrm{v}$ prvom rade operuje s pojmami reflexia a sebareflexia. P. Hartl, H. Hartlova, (2000: 503) chápu reflexiu ako istý druh sebapozorovania, obrátenia myslenia do seba, do vlastného vedomia a prežívania. Je to schopnost's odstupom nazerat' na seba ako na človeka, ktorý je učitel'om, pedagogickým zamestnancom školy, kolegom. V optimálnom prípade, by malo ist' vždy o neutrálny pohlad na seba a 
svoje konanie bez emocionálneho zaujatia, uvádza D. Goleman (1997: 55). B. Kosova (2013: 12) posudzuje vo všeobecnosti reflexiu vlastnej činnosti ako schopnost', ktorá ,je zásadnou spôsobilost'ou učitel'ov“, je to kompetencia $\mathrm{k}$ osobnému rastu, „kompetencia $\mathrm{k}$ sebarozvoju a sebazdokonal'ovaniu profesionála v edukácii“. $\mathrm{Na}$ základe našej schopnosti vnímat' seba samého a svoje správanie, reflektujeme vlastne existovanie, fungovanie v našom živote. Možno hovorit' o vykonávaní sebareflexie. Sebareflexia, resp. reflexia nám dáva odpovede na otázky Čo som urobil?, Ako som sa správal?, ale aj Ako som sa pri tom cítil?, Ako som uvažoval?. S. Babiakova (2014: 49) definuje reflexiu ako vnútornú tendenciu jedinca vnímat', rozpoznávat', kategorizovat' a popisovat' svoje osobné pocity, prežívané, myslenie, konanie, postoje, názory a očakávania. Sebareflexia, ako mentálna aktivita človeka nie je viazaná iba na výkon učitel'ského povolania. Patrí sem aj uvažovanie nad sebou samým v bežných aktivitách. V prípade učitel'a materskej školy, je to úvaha o priebehu výchovno-vzdelávacej činnosti a jej dopadu na jednotlivé deti. Je viazaná na konkrétne pedagogické situácie. Ide často o intuitívne premýšl'anie, ktoré nastupuje väčšinou vtedy, ak sa nám niečo nepodarí. Môže to byt' sebareflexia, ktorá nastúpi ihned' po pedagogickej situácii, alebo s krátkym časový odstupom. Podl'a J. Cap a J. Mares (2007: 507) je sebareflexia súčast'ou autoregulácie učenia sa. Aj napriek rozdielnej lexikálnej podobe slov reflexia a sebareflexia, vnímame tieto dva pojmy ako metakognitívnu činnost' učitel'a, ktorá je zameraná na seba samého.

372 Evaluácia a autoevaluácia učitel'a sú d'alšími pojmami, ktoré sa v spojitosti s reflexívnou kompetenciou učitel'a pomerne často vyskytujú. V literatúre dokonca existujú paralelne dva pojmy evaluácia/evalvácia. Obidva ekvivalenty sú v slovenčine akceptovatel'né. Ich synonymickým významom je odborné posudzovanie, posúdenie úrovne plnenia vopred stanovených kvalitatívnych a kvantitatívnych kritérií, hodnotenie.

S. Babiakova (2014: 49) hovorí, že ,autoevaluácia je vonkajším nástrojom vnútorného rozvoja učitel'a profesionála. Jej súčast'ou sú určené zámerné osobnostné a konatívne predpoklady: sebareflexia a autodiagnostika.“ Autoevaluáciu teda chápe S. Babiakova (tamtiež) ako nadradený pojem sebareflexii a autodiagnostiky. Rozlišuje vnútorné schopnosti človeka pozriet' sa na seba samého a naučené konatívne schopnosti a zručnosti používat' diagnostické nástroje pri vlastnej autodiagnostike. Po uskutočnení sebareflexie a poznania samého seba prostredníctvom autodiagnostiky možno prejst' na vyšší stupeň, za ktorý považujeme práve evaluáciu. Po uvedomení si odpovedí na otázky, z oblasti autodiagnostiky Aký som, z oblasti sebareflexie Čo som urobil?, Čo som svojim konaním spôsobil?, prichádzajú na rad otázky Ako to zmením, aby to v budúcnosti bolo lepšie?. Evaluácia je charakteristická tým, že nám dáva odpovede na otázky typu Aký by som chcel byt?, Čo chcem robit' inak?, Čo chcem zmenit' na sebe?. V. Spilkova (2010) konštatuje, že ,je to jedna z ciest k rozvíjaniu a prijatiu zodpovednosti za vlastný profesijný rozvoj“. Pomocou sebareflexie a autodiagnostiky, získavame o sebe informácie a pomocou autoevaluácie 
určujeme Čo?, Ako? a Prečo chceme na sebe zmenit?. Uvažujeme nad zmenou.

J. Prucha et al. (2001) zhrnul všetky podstatné činnosti, ktoré spoluvytvárajú reflexívnu kompetenciu. Uvažuje, že reflexívna kompetencia je zamýšl'anie sa nad sebou samým, nad svojou osobnost'ou, obzretie sa spät' za svojimi činmi, myšlienkami, postojmi, citmi, rekapitulovanie určitého úseku vlastného života či vlastného správania a rozhodovania sa v situáciách. Ciel'om je zhodnotit' samého seba, rozhodnút', čo a ako zmenit', zvolit' stratégiu pre budúcnost'. V. Spilkova (2010: 11) konštatuje, že reflexívna kompetencia je považovaná za jeden z určujúcich znakov profesionality učitel'a a jeho profesijného rastu. Aby sa reflexívna kompetencia stala skutočnou kompetenciou, je potrebné skombinovat' vnútornú snahu učitel'a vnímat' seba samého a naučené diagnostické postupy, pomocou ktorých sa učitel' zhodnotí s následným stanovením možnosti na svoj vlastný sebarozvoj.

\section{Záver}

Všetky delenia kompetencií obsahujú jednu spoločnú kompetenciu, ktorou je reflexívna kompetencia. Bez ohl'adu na prístup k deleniu kompetencií, je hodnotenie seba samého podstatným rysom d’alšieho učenia sa. Reflexívna kompetencia v sebe zahŕňa profesijné a zároveň nadprofesijné schopnosti, zručnosti a vedomosti. Možno konštatovat', že je kl'účovou pri sebahodnotení sa učitel'a a zároveň je kl'účovou pri dosahovaní d'alších profesijných ale aj nadprofesijných kompetencii učitel'a. Bez uvedenej kompetencie učitel' nevie posúdit' svoju profesionálnu úroveň a nevie si stanovovat' svoj d'alší sebarozvoj. Reflexívna kompetencia v sebe obsahuje tak vrodené dispozície človeka, jeho vnútornú motiváciu a snahu poznat' seba a svoje hranice, ako aj vedomosti a zručnosti, ktoré získal prostredníctvom vzdelávania a skúsenosti. Na dosiahnutie reflexívnej kompetencie je potrebné, aby učitel' disponoval nasledovnými vedomost'ami, zručnost'ami:

- $\quad$ súborom vedomostí o nástrojoch a metódach vhodných na vykonanie autodiagnostiky;

- $\quad$ súborom vedomostí o normách vhodných na porovnanie sa;

- súborom schopností a zručností diagnostikovat' samého seba $\mathrm{z}$ nadprofesijného pohl'adu a z pohl'adu profesionála, t.j. mal by mat' $\mathrm{k}$ dispozícii normu, ktorej sa chce priblížit', mal by vediet' zhodnotit' seba samého pomocou nástrojov a porovnat'sa s normou;

- súborom schopností a zručností reflektovat' seba, svoje správanie, konanie z nadprofesijného pohl'adu a z pohl'adu výkonu svojho povolania, a to, pokial' sa dá, bez emocionálneho zaujatia;

- $\quad$ súborom schopností, hl'adat' a nájst' priestor (svoje slabé miesta) na vykonanie zmien, (svoje silné miesta) na zlepšenie;

- súborom vedomostí, poznatkov o možnostiach realizovat' vlastný sebarozvoj;

- $\quad$ súborom schopností vyhodnotit' výsledky získané reflexiou a auto diagnostikou a na základe nich stanovit' optimálne d'alšie ciele, ktoré 
budú viest' k zmene, a následné zrealizovat' zmenu - čo je podstatou evaluácie.

I. Pavlov (2009: 82) poukazuje na reflexívnu kompetenciu učitel'ov, ako na hlavný faktor prinášajúci dlhodobejšie a trvalé zmeny v kvalite školy. Uvádza, že ,je potrebné, aby sa profesijný rozvoj zameral na tie kompetencie učitel'ov, ktoré podporujú tieto procesy“. Neschopnost' učitel'a reflektovat' svoju pedagogickú činnost' má za následok stagnáciu výchovno-vzdelávacieho procesu. J. Slavik, J. Lukavsky, P. Najvar, T. Janik (2015) konkretizujú dopad neschopnosti formulovat' priliehavý a odborne dokázatel'ný profesijný úsudok o výučbe. Stanovujú, že tento fakt môže do ,značnej miery brzdit' akúkol'vek učitel'skú motiváciu alebo snahu menit' svoje konanie s ciel'om zlepšovat' kvalitu výučby“.

Kvalitu výchovno-vzdelávacieho procesu považujeme za kl'účové kritérium pri celkovom hodnotení materskej školy. Učitel' bez reflexívnej kompetencie nemôže byt dôvodom, podporovatel'om a realizátorom zmeny celej školy, resp. učitel', ktorý dôkaze menit' seba, môže menit' celu školu. Dosahovanie potrebných profesijných kompetencii je proces prebiehajúci po celý čas profesijného života človeka. U učitel'a je reflexívna kompetencia dôležitá aj z toho dôvodu, že učitel' má za úlohu viest' v podobnom duchu edukantov, s ktorými pracuje. Učitel' sa pre nich stáva vzorom pri vytváraní ,aktívneho, tvorivého vzt’ahu k sebe samému ako k subjektu poznávania a regulovania vlastného učenia“, uvádzajú J. Komora, K. Vyrostekova (2015: 212). Aj preto môžeme hovorit' o učení sa ako efektívne učit' iných, o snahe vlastného sebarozvoja učitel'a, teda o schopnosti stále zlepšovat' svoje pracovne činnosti, ktorými je v tomto prípade učenie iných. Za hlavný spôsob podpory zvyšovania reflexívnej kompetencie považujeme pregraduálnu prípravu učitel'ov a hlavne v d'alšie vzdelávanie učitel'ov.

\section{Bibliographic references}

BABIAKOVA, S. et al. 2014. Progresivny ucitel. Autoevaluacia v teoriach a vyskumoch. 1. vyd. Banska Bystrica: Belianum, 264 p. ISBN 9788055707389.

BARABANOVNA, S. N. 2013. Profesionalny standard ucitela v zakladnej skole [online]. Moskva: Prvy september [cit. 2016-04-10]. Available online: http://festival.1 september.ru/articles/653908/.

BLEZ, H. - SIEGRIST, M. 2001. Klicove komptence a jejich rozvijeni. 1. vyd. Praha: Portal, 375 p. ISBN 8071784796.

BORISOVA, O. V. - VASBIEVA, D. G. - MALYKH, N. I. - VASNEV, S.A. - BIROVA, J. 2016. Problem of Using Innovative Teaching Methods for Distance Learning Students. International Electronic Journal of Mathematics Education, vol. 11, n. 5, pp. 1175-1184.

CAP, J. - MARES, J. 2007. Psychologie pro ucitele. 2.vyd. Praha: Portal, 2007.ISBN 9788073672737.

DUCHOVICOVA, J. - PETROVA, G. Osobnostne kompetencie absolventov ako predpoklad socialnej inkluzie. In Slavonic Pedagogical Studies Journal, vol. 5, n. 1, pp. 184-200. ISSN1339-8660

Slavonic Pedagogical Studies Journal, ISSN 1339-866o, Volume 5 Issue 2, September 2016 
GOLEMAN, D. 1997. Emocni inteligence. 1. vyd. Praha: Columbus. ISBN8085928485.

HARTL, P. - HARTLOVA, H. 2000. Psychologicky slovnik. Praha: Portal. ISBN 807178303X.

HORKA, H. - HAVEL, J. 2010. Ucitelstvi pro materske skoly. In Priprava ucitelu pre primarni a preprimarni vzdelavani v Cesku a na Slovensku. Vyvoj po roce 1989 a perspektivy. Vyskumny zamer: Ucitelska profese v mnenicich se pozadavcich na vzdelavani. 1. vyd. Praha: UK, pp. 131139. ISBN 9788072904860.

KASACOVA, B. - KOSOVA, B. 2006. Kompetencie a sposobilosti ucitela - Europske trendy a Slovensky pristup. In Profesijny rozvoj ucitela. 1. vyd. Presov: Rokus s.r.o., pp. 34-45. ISBN 8089055699.

KASACOVA, B. 2006. Dimenzie ucitelskej profesie. In Profesijny rozvoj ucitela. 1. vyd. Presov: Rokus s.r.o, pp. 19-33. ISBN 8089055699.

KASACOVA, B. - KOSOVA, B. 2007. Europske trendy a slovensky pristup $\mathrm{k}$ tvorbe ucitelskych kompetencii a sposobilosti ako vychodisko $\mathrm{k}$ profesijnym standardom. In Pedagogicke rozhlady - casopis pre skoly a skolske zariadenia, vol. 16, pp. 6-15. ISSN 13350404,

KOLLAROVA, D. 2012. Vychova detskeho divaka, posluchaca a citatela v podmienkach materskej skoly. In Predprimarne vzdelavanie v sucasnosti. Zbornik $\mathrm{z}$ vedecko-odbornej konferencie [online]. Presov: Presovska univerzita $v$ Presove, Pdagogicka fakulta, Slovensky vybor Svetovej organizacie pre predskolsku vychovu, pp. 180 - 191. [cit. 2016-08-01]. Available online: http://omep.sk/wp-content/uploads/2013/03/ZBO RNIKHLOHOVECWEB.pdf . ISBN 978-80-555-0703-3.

KOMORA, J. - VYROSTEKOVA, K. 2016. Vpyv metagognitivnych strategii ucenia na uroven sebahodnotenia skolkseho vykonu ziakov strednych skol. In Slavonic Pedagogical Studies Journal, vol.5, n. 1, pp. 174-183. ISSN1339-8660.

KOSOVA, B. 2013. Teoreticka reflexia praxe a profesijny rozvoj ucitela. In Ucitel na ceste k profesionlalite. Recenzovany zbornik vedeckych prac. 1 . vyd. Presov: FHPV PU a Skola plus, s.r.o., pp. 17-25 ISBN 9788055509846.

KRCMAROVA, T. - KOSTKOVA, K. - KARGEROVA, J. 2012. Ramec profesnich kvalit ucitele. Hodnotici a sebehodnotici arch. Praha: Narodni ustav pro vzdelavani. ISBN 9788087063644. [cit. 2016-07-12]. Available online: www.nuov.cz/uploads/AE/evaluacni_nastroje/08_Ramec_profesnic h_kvalit_ucitele.pdf

KYRIAC̄OU, Ch. 2012. Klicove dovednosti ucitele. Cesty k lepsimu vyucovani. Praha : Portal, pp. 168. ISBN 9788026200529.

LIPNICKA, M. 2009. Profesia ucitela v predpirmarnej edukacii. In Profesia ucitela v preprimarnej a primarnej edukacii v teórii a vyskumoch. Banska Bystrica: UMB, PF, Katedra elementarnej a predskolskej pedagogiky, pp. 192-201. ISBN 9788080839024.

MERTIN, V. - GILLEROVA I. et al. 2010. Psychologie pro ucitelky materske skoly. 1 vyd. Praha: Portal, 247 p. ISBN 9788073676278.

OPRAVILOVA, E. 2010. Priprava ucitelu pro preprimarni vzdelavani. In Priprava ucitelu pro primarni a preprimarni vzdelavani v Cesku a na 
Slovensku. Vyvoj po roce 1989 a perspektivy. Vyzkumni zamer Ucitelska profese v menicichse pozadavcich na vzdelavani. Praha: UK v Praze, PF, pp. 35-48. ISBN 9788072904860.

PAVLOV, I. 2009. Ucitelska profesia z pohladu profesijneho rozvoja a kontinualneho vzdelavania. In Profesia ucitela $v$ preprimarnej a primarnej edukacii $v$ teorii a vyskumoch. Banska Bystrica: UMB, PF, Katedra elementarnej a predskolskej pedagogiky, pp. 80-85. ISBN 9788080839024. Pelikan, J. 2011. Hledani teziste vychovy. Praha: Karolinum, 176 p. ISBN 9788024612652.

PODHAJECKA, M. 2011. Hra dietata. Edukacna platforma pre vyspelu osobnost. In Hra v predprimarnej edukacii. Zbornik z vedecko-odbornej konferencie s medzinarodnou ucastou. Presov: Presovska univerzita $\mathrm{v}$ Presove, Pedagogicka fakulta, Slovensky vybor Svetovej organizacie pre predskolsku vychovu, pp. 15-33. ISBN 9788055504674.

PORUBSKA, G. 2007. Dalsie vzdelavanie ucitelov - aktualny problem andragogickej pedeutologie. In Zaklady andragogickej pedautologie a socialnej andragogiky. Zbornik prispevkov $\mathrm{z}$ vedeckej konferencie konanej dna 26. septembra 2006. 1. vyd. Nitra: UKF PF, Katedra Pedagogiky, pp. 24-49. ISBN 9788080940867.

PRUCHA, J. - WALTEROVA, E. - MARES, J. 2001. Pedagogicky slovnik. 3. vyd. Praha : Portal, 292 p. ISBN 8071780294.

PRUCHA, J. 2002. Ucitel. Soucasne poznatky o profesi. 1. vyd. Praha: Portal, 149 p. ISBN 8071786217.

376 PRUCHA, J. 2009. Moderni pedagogika. 4. vyd. Praha: Portal, 2009, 474 p. ISBN 9788073675035.

SLAVIK, J. - LUKAVSKY, J. - NAJVAR, P. - JANIK, T. 2015. Profesni soud o kvalite vyuky: predem a nasledne strukturovana reflexe. In Pedagogika. [online], vol. 65, n. 1, pp. 5-33. [cit. 2016-04-10]. Available online: http://userweb.pedf.cuni.cz/wp/pedagogika/

SPILKOVA, V. 2010. Reflexe promen Pripravy ucitelu pro predprimarni a primarni vzdelavani $\mathrm{v}$ CR a SR. In Priprava ucitelu pre primarni a preprimani vzdelavani v Cesku a na Slovensku. Vyvoj po roce 1989 a perspektivy. Vyskumny zamer: Uciteska profese $\mathrm{v}$ mnenicich se pozadavcich na vdelavani. 1. vyd. Praha: UK, pp. 7-34. ISBN 9788072904860.

SPILKOVA, V. et al. 2004. Soucasne promeny vzdelavani ucitelu. Praha: Paido. ISBN 8073150816.

SVEC, V. 1994. Autodiagnostika pedagogicke cinnsoti ucitele - modnost nebo potreba? In Pedagogika, vol. XLIV, n. 2, pp. 105-106. ISSN 33303815 .

TOMKOVA, A. - SPILKOVA, V. - PISOVA, M. - MAZACOVA, N. KRCMAROVA, T. - KOSTKOVA, K. - KARGEROVA, J. 2012. Ramec profesnich kvalit ucitele. Hodnotici a sebehodnotici arch. Prague: Narodni ustav pro vzdelavani. ISBN 9788087063644. [cit. 2016-07-12]. Available online:

http://www.nuov.cz/uploads/AE/evaluacni_nastroje/08_Ramec_profesnich _kvalit_ucitele.pdf

Slavonic Pedagogical Studies Journal, ISSN 1339-866o, Volume 5 Issue 2, September 2016 
VASBIEVA, D. G. - KALUGINA, O. A. 2016. An Analysis of Students' Intercultural Competence Levels in a Non-Linguistic Higher School. XLinguae, vol. 9, n.3, pp. 58-69. DOI: 10.18355/XL.2016.09.58-69

1 www.minedu.sk/data/att/8686.pdf

2 http://eur-lex.europa.eu/legal-content/SK/TXT/PDF/?uri=CELEX:32006 $\mathrm{H} 0962 \&$ qid $=1468395662359 \&$ from $=\mathrm{SK}$

$3 \mathrm{http}: / /$ pkrmpc.dev2010.lomtec.com/stranka/odborna-aktivita-1-1-1

4 www.минобрнауки.рф/документы

5 http://jazykovaporadna.sme.sk/q/3627/\#ixzz4IiHXxmvb

PaedDr. Eva Pupíková

Department of Education

Faculty of Education

Constanine the Philosopher University

Dražovská cesta 4, 94974 Nitra

Mehodological-educational center Bratislava

Ul. kozmonautov 5, 94901 Nitra

Slovakia 